\title{
Development of Children's Cognitive Aspects in Recognizing Surrounding Objects by Function with a combination of Direct Instruction, Make a Match, and Talking Stick learning models
}

\author{
Ma'rifah *, Ali Rachman, Aslamiah \\ Master Program of Early Childhood Education, Universitas Lambung Mangkurat, Banjarmasin 70123, \\ Indonesia
}

Article history:

Submission January 2021

Revised April 2021

Accepted April 2021

*Corresponding author:

E-mail:

hjmarifah366@gmail.com

\begin{abstract}
This Classroom Action Research was conducted in two cycles with three meetings to practice learning models that are fun for children. The subjects of this study were 16 children in Group B Kindergarten Putera Bangsa Banjarmasin. Fun learning models that are applied in this study were Direct Instruction, Make A Match, and Talking Stick to developing children's cognitive aspects in recognizing surrounding objects by their function. Analysis of the descriptive qualitative data, the teacher's activity reached $\geq 24$ with the "Very active" category, children's activities reaching $\geq 82$ in the "Very active" category and learning results showed very well developed. This study showed that a combination of the three fun models had a positive impact on the development of early childhood cognitive aspects.
\end{abstract}

Keywords: Direct instruction, make a match, talking stick.

\section{Introduction}

Education is an aspect that must be lived by society in every aspect. Education as a system can be seen as academic learning, beyond formal schooling and informal education that can come from nature and culture where they live and interact (Dhungana, 2020).

Nurkholis (2013) defines education as a process that includes three dimensions, individual, community, or individual national community, and the entire content of reality. These three dimensions in material and spiritual form play a role in determining one's nature, destiny, human form, and society. Hence, through education, young people may have a key cultural mechanism to thread their lives into the culture's bigger picture not only of the good life but also of a life of good (Moran, 2018).

Education is important for humans to live in society. It has an important task in preparing young people for their participation in society (Veugelers \& Groot, 2019). Furthermore, education that opens for all learners is key to maximize the impact of education on society and ensuring its success and sustainability (Ossiannilsson et al., 2016). According to Hasbullah (2009), through education, the human personality is strived to be following the values and culture in society. These cultural values are formed by a particular community and not individually (Dyczewski \& Slawik, 2016) since society involves groups of people from various cultural, ethnic, racial, religious, 
and social conditions (MM, 2019). Through education, humans are developed following the values in society and the prevailing culture (Darmiyati \& Elisa, 2018). It can be the core values that central to the survival of a viable and identifiable cultural society (Secombe, 2016).

The place to provide education is usually called a school. Schools as educational institutions teach science, skills, and attitudes. Readiness for school is the basis for happiness in school and good performance (Brenner, 1957). In addition, the school has an important role in shaping children's character, because children spend enough time studying which will shape their personality there (Ahmad, 2014); (Baharuddin \& Dalle, 2019). Character is about who we are and who we become including the virtues of responsibility, honesty, self-reliance, generosity, self-discipline, and a sense of identity and purpose (Arthur, Powell, \& Lin, 2014). The importance of school in shaping children's character is by imparting in them values such as curiosity, achievement, benevolence, and citizenship (Berson \& Oreg, 2016). For instance, student subjective well-being or happiness ratings are part of school climate assessment within school improvement plans (Cleveland \& Sink, 2017). Hence, the moment of games and playful activities creates the basis for a new period in personality development that it is the education moment (Bissoli, 2014).

Early childhood education is the earliest education. The early childhood sector has positioned itself within the education discourse which one of the reasons is children as future human capital (Sims \& Brettig, 2018). The years from birth to age 5 are viewed as a critical period for developing the foundations for thinking, behaving, and emotional well-being (Bakken et al., 2017). According to Wijana (2014) states that young learners need the education to fulfill aspects of child development. Aspects that must be developed in early childhood education are: (a) Religious and Moral Values; (B) Social Emotional; (c) Cognitive; (d) Language; and (e) PhysicalMotor. During early childhood, children indeed develop linguistic, cognitive, social, emotional, and regulatory skills that predict their later functioning in many domains (Trawick-Smith, 2014). The ecological features of preschool programs directly impact children's development (Mofrad, 2012). Early childhood is a crucial period for physical, cognitive, and psychosocial development (Fernandez, 2014). In this study, researchers examined the cognitive aspects of the early childhood phase.

Early Childhood Education is education that focuses on the foundation towards growth and motoric values, moral and religion, social-emotional, cognitive, language, and art. Early childhood and early childhood education are an important basis for later development, educational performance, and pathways as well as for lifelong learning and well-being (Weinert et al., 2016). It is in line with the uniqueness and stages of early childhood development. The development of children has been generally understood to be about physical and psychological growth (Woodhead, 2009) that is associated with optimal adult health and productivity (Tran et al., 2019. Which can be different for every child. Every child is different and has its uniqueness (Purwanti et al., 2018).

In the past, the orientation of early childhood education was only to develop academic abilities (Dalle \& Ariffin, 2018). Meanwhile, character development as an aspect of child development is neglected. This violates the nature of early childhood education which should aim to develop all the potential and basic intelligence possessed by every child. Indonesia is currently facing a severe problem that must be overcome, namely a prolonged multidimensional crisis (Salasiah, Asniwati, \& Effendi, 2018). The multidimensional crisis is including sanitary, social, economic, political, ecological, and ideological crises (Prieur, 2020). Fortunately, in recent years there have been changes that have made more parents understand the importance of early childhood education (Safitri, Ahmad, \& Saleh, 2018).

One of the most important aspects of early childhood education is the cognitive aspect. Suryaningsih \& Rimpiati (2018) said that 
cognitive is the ability to learn or think. Furthermore, cognitive is the ability to learn new skills and concepts to understand their environment, and the skills to use memory and solve simple problems. Cognitive ability refers to the degree to which a person can think, reason, understand and remember information, solve problems, and learn (Gottfredson, 1997; Robbins, 2011; Kiely, 2014).

Another focus in this research is the importance of fun models in early childhood education. Izzaty (2018) states that joy or happiness affects students' ability to adapt to their social environment and develop their cognitive. This is in line with Zosh, et al. (2017), who stated that learning through play can bring positive healthy development for each child.

Besides, research done by Vogt et al. (2018) shows that higher learning gains overall for the play-based approach. Even in higher education, games have a positive impact on learning goals (Vlachopoulos \& Makri, 2017). Play is also recognized by the United Nations as every child's right (Murray, 2018). From children's perspective, play and learning are not always separate in practices during the early years (Samuelsson \& Carlsson, 2008). Play supports the formation of the safe, stable, and nurturing relationships with all caregivers that children need to thrive (Yogman et al., 2018)

Based on preliminary observations at Kindergarten Putera Bangsa in Banjarmasin, within the scope of development, it was revealed that fourteen out of sixteen students still had difficulty recognizing objects around them based on function. Only two students can recognize objects around with functions. Therefore, learning outcomes in achieving goals according to indicators have not been successful, because almost $80 \%$ of students have not been able to recognize objects based on function. The reason is the use of inappropriate learning models that are less attractive to children.

This issue must be considered. If students fail to recognize surrounding objects by their function, it will have a serious impact on the cognitive aspects of students. In the end, it will have an impact on the quality of the school. Organizational views of quality have evolved. Schools compete with each other through quality improvement. Quality progress was common, but now it is slowly moving in a positive direction. At first, quality was not considered important, but now it is the most important thing in an organization (Asniwati; Suriansyah et al., 2019).

This assumption needs to be endeavored to improve cognitive development skills in recognizing objects around them based on function. The cognitive development of children in kindergarten requires a learning model suitable for childhood. With suitable model children will learn in a fun way, and there is no coercion from others so that children easily accept the material presented by the teacher.

Researchers chose a combination of Direct Instruction, Make A Match, and Talking Stick Learning Model. According to Suryaningsih \& Rimpiati (2018), a learning model is a plan or pattern that can be used to form a curriculum (long-term learning plans), design learning materials, and guide learning in class or others. The learning model used in this study is designed to support the teaching and learning process of students related to declarative knowledge and procedural knowledge that is well structured and taught in a gradual pattern of activities.

The Direct Instruction learning model is a direct learning model that is a teaching approach specifically designed to support the student learning process related to wellstructured declarative knowledge and procedural knowledge that can be taught with a gradual activity pattern and direct learning models can be an effective way to teach factual and structural information and knowledge. Make A Match Learning Models was first discovered in 1994 by Lorna Curran (Huda, 2013). This learning method is a presentation technique that is mastered by a teacher to present subject matter to students in the class either individually or in groups so that the subject matter can be absorbed, understood, and utilized by students properly. According to Zosh et al. (2017), playing has 
become children's work to achieve children's development. Playing is a fun activity that is not serious, flexible, imaginative, and transformative. The definition of play can a physical or mental leisure activity that is undertaken purely for enjoyment or amusement and has no other objective (PTUK, 2017).

Playing is an activity that is always carried out by children every day, because for them playing is part of life (Sujiono, 2013) Early childhood cannot differentiate between playing, studying, and working. All children enjoy the game and will continue to do so wherever they have the opportunity.

Piaget in Sujiono (2013) states that playing is something that is done repeatedly and raised for pleasure/satisfaction for someone. While Parten in Sujiono (2013) views "playing activities as a means of socialization, it is hoped that playing can give children an agreement to explore, discover, express feelings, be creative, and learn in a fun way". Fun activities have positive results on the development of the cognitive aspects of children.

Schools and parents must have a joint role in improving students' cognitive abilities (Poernamawijaya et al., 2018). It is proven that the development of student learning outcomes is supported by the method used by teachers in schools is coupled with the ability of the principal to regulate the quality of education in schools. Another factor to support the development of student learning outcomes is the ability of teachers to deliver learning material that motivates and can coordinate children in the class (Metroyadi \& Mardhiah, 2018).

\section{Material and Methods}

This type of research is a classroom action research conducted at Kindergarten Putera Bangsa Banjarmasin in the first semester, the academic year 2020/2021. The research subjects were 16 students consisting of 8 boys and 8 girls. This classroom action research procedure was carried out in 2 cycles consisting of cycle 1 with 2 meetings and cycle 2 with 1 meeting. Each meeting includes several stages, namely planning, implementation, observation, and reflection (Legiman, 2015)
The data were analyzed through teacher activities, student activities, and student cognitive development learning outcomes in recognizing objects around them based on function. The success indicator in this study is said to be successful if the teacher's activity reaches $79 \%-100 \%$ in the very good category, student activity if the value obtained is $81 \%$ $100 \%$ in the very active category and the classical cognitive development of students is up to $82 \%-100 \%$ with very active category and cognitive ability to recognize surrounding objects by its function of getting a score **** with a very developed category.

\section{Results and Discussion}

Based on the results of the study, there were 3 (three) meetings consisting of cycle I (meeting 1 and meeting 2) and cycle II (meeting 3). The activities carried out are observing teacher activities, student activities, and student learning outcomes on aspects of cognitive abilities in recognizing surrounding objects by their function. Sixteen students were involved in this study, consisting of 8 boys and 8 girls.

This research on aspects of cognitive abilities in recognizing surrounding objects by its function uses a combination of Direct Instruction, Make A Match model, and Talking Stick to group B students at Kindergarten Putera Bangsa Banjarmasin, which conducted 3 meetings was declared successful. Students know the material through sample images that can increase student knowledge, indirectly in the aspect of cognitive abilities students can classify objects to recognize surrounding objects by their function. This is in line with Sudono (2000), who states that the reference for choosing teaching methods for Group B 0-6 years involves students in learning activities, therefore in schools students should be invited to choose the materials they want to explore.

\section{Teacher's activities}

Teacher activity at the first meeting got a score of 12 and the second meeting got a score of 18 and the third meeting increased to a score of 21. Based on observations of teacher activities, the teacher continues to increase 
the score at each meeting. Learning activities were done by continuing to make improvements from every aspect that is still lacking. This increase occurs because the teacher is reflecting on and correcting mistakes and trying to manage to learn.

Furthermore, the teacher was able to master the class to understand activities that can provide understanding to children about the cognitive aspects of recognizing surrounding objects by their function so that the results of each meeting can be improved. Teaching carried out by the teacher has reached very good criteria, learning activities are following the set indicators, and the implementation of the teacher's activities are successful.

The teacher's activities in developing students' cognitive abilities in recognizing objects around them based on function using fun learning models such as Direct Instruction, Make A Match, and Talking Stick was proven to be increased. This was evident from the teacher's activities during the 3 meetings which continued to increase from meeting 1 to meeting 3 . At meeting 1 , the score was 12. At the second meeting, the score was 18 in the good category. In the second cycle of meeting 3 , the score was 21 in the very good category. In increasing teacher activity by applying the Direct Instruction, Make A Match, and talking stick models, first, the teacher prepares several cards containing several concepts or topics that are suitable for the picture review session, and each child gets one card to pair and the teacher guides the child in pairing the cards (Aqib, 2013).

\section{Students activities}

Students' activities in developing cognitive abilities in recognizing surrounding objects by their function using fun learning models such as Direct Instruction, Make A Match, and Talking Stick have increased. At this meeting, students pair / match the picture of a pot with its function for cooking vegetables, a picture of a frying pan with its function for frying fish, and a picture of a kettle with its function to boil water. At meeting 1, the category obtained was not good because students only received an average of $62 \%$ based on the indicators assessed in children's activities.

At the second meeting, the activities carried out by pairing plates with their function as a place to eat, a bowl with its function as a place for soup, and a glass with its function as a container for drinking water experienced a slight increase in the category obtained quite well from the average. about $80 \%$ based on indicators assessed based on student activity.

In the second cycle, the third meeting paired the spoon with its function as a tool for making rice, the fork as a tool for making noodles, and a knife as a cutting tool which was obtained based on the fairly good category but the score was increased by around $89 \%$.

Based on the indicators assessed about student activities, there is an increase in student activity continuously both from the average score obtained and the category in developing students' cognitive abilities using the Direct Instruction, Make A Match, and Talking Stick learning models through the introduction of surrounding objects by its function in Group B Kindergarten Putera Bangsa Banjarmasin. Student activities have increased and can achieve the desired indicators of success. Student activity is declared successful if the classical activity of students reaches the criteria for a score of "very active" $\geq 80 \%$. So, it can be concluded that students successfully participate in learning using Direct Instruction, the Make A Match model, and Talking Stick in recognizing surrounding objects by their function.

At the first meeting, the activity of pairing/matching objects/equipment in the house obtained classical completeness of $12.5 \%$ or as many as 2 out of 16 children or 1 pair of students who managed to achieve the highest point compared to the others. student pair.

In the second meeting, the activity of pairing/matching objects with their partners, namely kitchen equipment obtaining 50\% classical completeness or as many as 8 out of 16 students or 4 pairs of students who won the highest points compared to other pairs of students.

At the third meeting, the pairs/matching of object pictures according to their function 
were $75 \%$ classical completeness or as many as 12 students out of 16 students or 6 pairs of students who won the highest points compared to other pairs of students. At the fourth meeting, the activity of pairing / matching numbers according to the number of pictures about school equipment obtained classical completeness of $87.5 \%$ or as many as 14 students out of 16 students, these results indicate that they have achieved the expected indicators.

At the first meeting, completeness reached $56 \%$ of successful students. While at the second meeting, completeness reached $75 \%$ of successful students. Furthermore, at the third meeting, completeness reached 87, $50 \%$ of successful students. We can say that the learning outcomes at the third meeting achieved the expected success indicators that reached $\geq 80 \%$ of children got $\geq 3\left(^{* * *}\right)$. It can be concluded that the use of fun learning models Direct Instruction, Make A Match, and Talking Stick in recognizing surrounding objects based on function is declared successful. There was an increase in the value of the results of the abilities obtained by students because students can master the learning material taught by the teacher so that the results of students' abilities at each meeting tend to increase.

Table 1. Comparison of observations of teacher activities, student activities, and student learning outcomes

\section{Cycle I Cycle II}

Meeting $1 \quad$ Meeting $2 \quad$ Pertemuan 3

\begin{tabular}{cccc}
\hline Teacher Activity & $\mathbf{5 0 \%}$ & $\mathbf{7 1 \%}$ & Teacher Activity \\
Children's Activities & $\mathbf{6 2 \%}$ & $\mathbf{8 0 \%}$ & Children's Activities \\
Learning outcomes & $\mathbf{5 6 \%}$ & $\mathbf{7 5 \%}$ & Learning outcomes
\end{tabular}

\section{Conclusion and Recommendation}

The teacher's activities in developing cognitive about recognizing surrounding objects by their function used a fun learning model of Direct Instruction, Make A Match, and Talking Stick for group B children at Kindergarten Putera Bangsa Banjarmasin was successful with very good results. Students' activities in developing cognitive abilities about recognizing surrounding objects by their function using a fun learning model direct instruction, make a match, and talking stick in group $B$ children at Kindergarten Putera Bangsa Banjarmasin have improved in each cycle with very active criteria. Fun learning models such as Direct Instruction, make a match, and the talking stick can develop children's cognitive abilities in recognizing surrounding objects by its function in group B of Kindergarten Putera Bangsa Banjarmasin with very well developed criteria. This study only focuses on identifying objects based on function, a more enjoyable learning model can be used in further research to measure cognitive aspects or other aspects of early childhood students.

\section{Acknowledgment}

My gratitude to the head of the program, secretariat, and lecturers of the Early Childhood Education Master Program at Lambung Mangkurat University, Banjarmasin, who provided input and suggestions for writing this article. We appreciate the Principal of the Kindergarten Putera Bangsa Banjarmasin and the teachers for helping in this research. May Allah Subhana wa Taala bless us all.

\section{References}

Ahmad, K. I. (2014). Penerapan pendidikan karakter, pendekatan sesosifit (spiritual, emosional, sosial, intelektual, fitrah) 
melalui layanan mimbingan dan Konseling. Retrieved from ULM Repository:

Aqib, Z. (2013). Model-model, media, dan strategi pembelajaran kontekstual (inovatif) (cetakan pertama). Bandung: Yrama Widya.

Arthur, J., Powell, S., \& Lin, H.-C. (2014). Foundations of character: methodological aspects of a study of character development in three- to six-year-old children with a focus on sharing behaviours. European Early Childhood Education Research Journal, 22 (1), 105-122.

Asniwati. (2015). Pengembangan manajemen terpadu untuk penyelenggaraan pendidikan pada sekolah dasar di Kota Banjarmasin. Prosiding SEMNAS PS2DMP ULM, 1(1), 9-16.

Baharuddin, B., \& Dalle, J. (2019). Transforming learning spaces for elementary school children with special needs. Journal of Social Studies Education Research, 10(2), 344-365.

Bakken, L., Brown, N., \& Downing, B. (2017). Early childhood education: the long-term benefits. Journal of Research in Childhood Education, 31(2), 255-269.

Berson, Y., \& Oreg, S. (2016). The role of school principals in shaping children's values. Psychological Science, 27(12), 1539-1549.

Bissoli, M. d. (2014). Development of children's personality: the role of early childhood education. Psicol. estud., 19(4),110.

Brenner, A. (1957). Nature and meaning of readiness for school. Merrill-Palmer Quarterly (1954-1958), 3(3), 114135.

Cleveland, R. E., \& Sink, C. A. (2017). Student happiness, school climate, and school improvement plans: implications for school counseling practice. Professional School Counseling, 21(1), 1-10.

Dalle, J., \& Ariffin, A. M. (2018). The impact of technologies in teaching interaction design. 10(Special Issue 04-Special Issue), Journal of Advanced Research in Dynamical and Control Systems, 1779-1783.

Darmiyati, \& Elisa, S. (2018). Meningkatkan hasil belajar matematika materi operasi perkalian dan pembagian pecahan melalui model demonstrasi kombinasi dengan problem based learning dan pair checks siswa kelas $\mathrm{V}$ Sekolah Dasar. J-Instech: Journal of Instructional Technology /Jurnal Teknologi Pendidikan, 1(1), 10-18.

Dhungana, R. (2020). Corridors of knowledge for peace and development. Sustainable Development Policy Institute, 297-228.

Dyczewski, L., \& Slawik, Z. (2016). Values - the core of culture. Politeja, 44, 143-170.
Fernandez, E. (2014). Early childhood: Dimensions and contexts of development and well-being. In Ben-Arieh A., Casas F., Frønes I., Korbin J.(eds), Handbook of Child Well-Being. Dordrecht: Springer.

Gottfredson, L. (1997). Mainstream science on intelligence: an editorial with 52 signatories, history, and bibliography. Intelligence, 24, 13-23.

Hasbullah. (2009). Dasar-dasar ilmu pendidikan. Retrieved from Rajagrafindo Persada: http://www.rajagrafindo.co.id/produk/dasar-dasarilmu-pendidikan/

Huda, M. (2013). Model-Model pengajaran dan pembelajaran: Isuisu metodis dan paradigmatis. Retrieved from Pustaka Pelajar: https://pustakapelajar.co.id/buku/model-modelpengajaran-dan-pembelajaran/

Izzaty, R. E. (2018). Happiness in early childhood. Psychological Research and Intervention, 1(2), 64-77.

Kiely, K. M. (2014). Cognitive function. In Michalos A.C. (eds) Encyclopedia of Quality of Life and Well-Being Research. Dordrecht: Springer.

Legiman. (2015). Penelitian Tindak Kelas (PTK) (pp. 1-15). Retrieved from https://www.google.com/url?sa=t\&source=web\&rct=j\& url=http://lpmpjogja.kemdikbud.go.id/wpcontent/uploads/2015/02/Penelitian-Tindakan-Kelas-

PTK-

legiman.pdf\&ved=2ahUKEwjK7aGUlZroAhWGyTgGH c20BC0QFjADegQIARAB\&usg=AOvVaw3WLrUuvxMRRWLfrtTXMTd

Metroyadi, \& Mardhiah, A. (2018). Efforts to Develop Children Fine Motor Skills Through Sticking Picture Properly by Using Combination of Explicit Instruction Model and Assignment Media Utilizing Natural Materials. Journal of K6, Education and Management, 1(2), 19-24.

MM, D. (2019). Managing cultural diversity: inclusive and exclusive approaches. World Affairs: The Journal of International Issues, 23(4), 26-35.

Mofrad, S. (2012). Opportunity in early childhood education: Improving interaction and communication. Procedia Social and Behavioral Sciences, 46 , 241-246.

Moran, S. (2018). Purpose-in-action education: Introduction and implications. Journal of Moral Education, 47(2), 145158.

Murray, J. (2018). The play's the thing. International Journal of Early Years Education, 26(4), 335-339.

Nurkholis. (2013). Pendidikan dalam upaya memajukan teknologi. Jurnal Kependidikan, 1(1), 24-44.

Ossiannilsson, E., Altinay, Z., \& Altinay, F. (2016). Transformation of teaching and learning in higher education towards open learning arenas: A question of 
quality. In Blessinger P. \& Bliss T. (Eds.), Open Education: International Perspectives in Higher Education (pp. 159178). Cambridge, UK: Open Book.

Poernamawijaya, L. W., Sulaiman, S., Suriansyah, A., \& Dalle, J. (2018). Contribution on supervision of supervisor, principals motivation, kindergarten teacher performance to improving the Kindergarten Quality in West Banjarmasin, Indonesia.

Prieur, J. (2020). Critical warning! Preventing the multidimensional apocalypse on planet Earth. Ecosyst Serv., 45.

PTUK. (2017). Definition of Play . Retrieved from PTUK: Play Therapy United Kingdom: https://playtherapy.org.uk/ChildrensEmotionalWellBei ng/AboutPlayTherapy/MainPrinciples/PlayDefinition

Purwanti, R. Y., Suriansyah, A., Aslamiyah, A., \& Dalle, J. (2018). Introducing language aspect (english) to early childhood through the combination of picture and picture model, talking stick model, flashcard media, and movement and song method in B1 group at Matahariku Bilingual Kindergarten Landasan Ulin Tengah, Banja. Retrieved from Semantic Scholar: https://www.semanticscholar.org/paper/INTRODUCIN G-LANGUAGE-ASPECT-(ENGLISH)-TO-EARLY-THEPurwanti-

Suriansyah/2daf58115084a661e98fd0c2cc1f10ac0300502b

Robbins, T. W. (2011). Cognition: The ultimate brain function. Neuropsychopharmacology,36 (1), 1-2.

Safitri, M. E., Ahmad, K. I., \& Saleh, M. (2018). Development of child independence through model picture and picture, examples non examples model and practical method directly activities of learning practical life in group B Kasih Ibu Kindergarten, Banjarmasin, Indonesia. European Journal of Education Studies, 5(7), 64-80.

Salasiah, Asniwati, \& Effendi, R. (2018). Instilling character values in early childhood in the perspective of curriculum and parenting (multi-site study in PAUD Islam Sabilal Muhtadin and PAUD Mawaddah, Banjarmasin, Indonesia). European Journal of Education Studies, 5(7), 36-48.

Samuelsson, I. P., \& Carlsson, M. A. (2008). The playing learning child: towards a pedagogy of early childhood. Scandinavian Journal of Educational Research, 52 (6), 623641.

Secombe, M. (2016). Core values and human values in intercultural space. Politeja, 44, 265-276.

Sims, M., \& Brettig, K. (2018). Early childhood education and early childhood development: Do the differences matter? Power and Education, 10(3), 275-287.
Sudono, A. (2000). Sumber belajar dan alat permainan untuk pendidikan usia dini (Edisi Pert). Jakarta: Gramedia Widiasarana Indonesia.

Sujiono, Y. N. (2013). Konsep dasar pendidikan anak usia dini (Edisi Pert). Jakarta: Rineka Cipta.

Suriansyah, A., Aslamiah, Noorhapizah, Winardi, I., \& Dalle, J. (2019). The relationship between university autonomy, lecturer empowerment, and organizational citizenship behavior in indonesian universities. Journal of Social Studies Education Research, 10(4), 127-152.

Suryaningsih, N. M., \& Rimpiati, N. L. (2018). Implementation of game-based thematic science approach in developing early childhood cognitive capability. Jurnal Obsesi : Jurnal Pendidikan Anak Usia Dini, 2(2), 194-201.

Tran, T. D., Holton, S., Nguyen, H., \& Fisher, J. (2019). Physical growth: is it a good indicator of development in early childhood in low- and middle-income countries? BMC Pediatrics, 19, 276.

Trawick-Smith, J. (2014). Early childhood development (6th ed.). Boston, MA: Pearson.

Veugelers, W., \& Groot, I. (2019). Theory and practice of citizenship education. in Veugelers W. (Ed.), Education for Democratic Intercultural Citizenship (pp. 14-41). Leiden, Boston: Brill.

Vlachopoulos, D., \& Makri, A. (2017). The effect of games and simulations on higher education: a systematic literature review. International Journal of Educational Technology in Higher Education, 14 (22),114-119.

Vogt, F., Hauser, B., Stebler, R., Rechsteiner, K., \& Urech, C. (2018). Learning through play - pedagogy and learning outcomes in early childhood mathematics. European Early Childhood Education Research Journal , 26(4), 589-603.

Weinert, S., Linberg, A., Attig, M., Freund, J.-D., \& Linberg, T. (2016). Analyzing early child development, influential conditions, and future impacts: prospects of a German newborn cohort study. International Journal of Child Care and Education Policy, 10 (7), 187-192.

Wijana, W. D. (2014). Konsep-konsep dasar pendidikan anak usia dini. Kurikulum PAUD https://doi.org/10.1101/112268, 40 .

Woodhead, M. (2009). Child Development and the Development of Childhood. In Qvortrup J., Corsaro W.A., Honig MS. (eds), The Palgrave Handbook of Childhood Studies. London: Palgrave Macmillan.

Yogman, M., Garner, A., Hutchinson, J., Hirsh-Pasek, K., \& Golinkoff, R. M. (2018). The Power of Play: A Pediatric Role in Enhancing Development in Young Children. Pediatrics, 142(3), 113-119. 
Zosh, J. M., Emily, J. H., Jensen, H., Liu, C., Neale, D., HirshPasek, K., \& Whitebread, D. (2017). Learning Through Play : A Review of the Evidence (White Paper). 